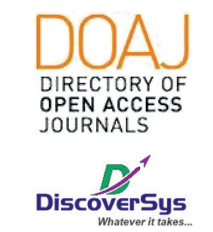

Published by DiscoverSys

\section{Relaksasi autogenik menurunkan keluhan gastritis pada orang dengan infeksi HIV-AIDS (ODHA) di RSUD Wangaya, Bali, Indonesia}

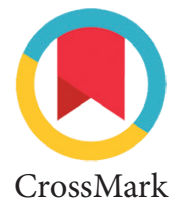

\author{
I Wayan Surasta, ${ }^{*}$ I Ketut Suardana, I Ketut Labir
}

\section{ABSTRACT}

Background: The current society is demanded many obligations and responsibilities in daily life. This situation can affect the mental stress that leads to stress in facing many problems of life. Psychological stress has an impact on system disturbances in the digestive organs such as gastritis. People with HIV/AIDS (ODHA) are often faced with this condition, so one of the efforts that can be done is to do autogenic relaxation. This study aims to determine the differences in gastritis complaints of ODHA people before and after autogenic relaxation.

Methods: A quasi-experimental study with pre-test and post-test without a control group was conducted among 21 respondents at Countermeasures AIDS at Badung Regency from May-September 2017.
Variables assessed in this study were gender, type of works, marital status, the origin of respondents, and the symptoms of respondents before and after autogenic relaxation intervention. Data were analyzed using SPSS version 17 for Windows.

Results: Most of ODHA patients were males (61.9\%), followed by working as housewives (28.6\%), marriage (81.0\%), and living in North Kuta (28.6\%). There was a significant difference in the average value of gastritis symptoms before (1.77) and after autogenic relaxation treatment $(1.53)(p=0.002)$.

Conclusion: Autogenic relaxation therapy can reduce the symptoms of gastritis among ODHA patients at Wangaya Hospital, Bali, Indonesia.

Keywords: Autogenic Relaxation, ODHA, Gastritis, Symptoms, Wangaya Hospital

Cite This Article: Surasta, I.W., Suardana, I.K., Labir, I.K. 2020. Relaksasi autogenik menurunkan keluhan gastritis pada orang dengan infeksi HIV-AIDS (ODHA) di RSUD Wangaya, Bali, Indonesia. Intisari Sains Medis 11(1):301-305. D0I: 10.15562/ism.v11i1.564

\title{
ABSTRAK
}

Latar belakang: Masyarakat saat ini dituntut dengan banyak kewajiban dan tanggung jawab dalam kehidupan sehari-hari. Keadaan ini akan berdampak pada tekanan mental yang mengarah pada stres dalam menghadapi banyak masalah kehidupan. Tekanan mental akan berdampak pada organ pencernaan seperti gastritis. Penderita HIV/ AIDS (ODHA) kerap dihadapkan pada kondisi ini sehingga salah satu upaya yang dapat dilakukan adalah melakukan relaksasi autogenik. Penelitian ini bertujuan untuk mengetahui perbedaan keluhan gastritis pada ODHA sebelum dan sesudah relaksasi autogenik.

Metode: Sebuah penelitian eksperimental-semu dengan pre-test dan post-test tanpa kelompok kontrol dilakukan terhadap 21 responden pada Penanggulangan AIDS di Kabupaten Badung dari Mei-September
2017. Variabel yang dinilai dalam penelitian ini adalah jenis kelamin, jenis pekerjaan, status perkawinan, asal responden, dan gejala responden sebelum dan sesudah intervensi relaksasi autogenik. Data dianalisis menggunakan SPSS versi 17 untuk Windows.

Hasil: Sebagian besar pasien ODHA adalah laki-laki (61,9\%), diikuti dengan bekerja sebagai ibu rumah tangga (28,6\%), menikah $(81,0 \%)$, dan tinggal di Kuta Utara (28,6\%). Ada perbedaan yang bermakna dalam nilai rata-rata gejala gastritis sebelum $(1,77)$ dan setelah perawatan relaksasi autogenik $(1,53)(p=0,002)$.

Kesimpulan: Terapi relaksasi autogenik dapat mengurangi gejala grastritis di antara pasien ODHA di Rumah Sakit Wangaya, Bali, Indonesia.
Dosen Departemen Keperawatan, Poltekkes Denpasar, Bali, Indonesia

*Korespondensi: I Wayan Surasta; Lecturer of Nursery Departement of Poltekkes Denpasar, Bali, Indonesia; wayansurasta65@gmail.com

Diterima: 11-07-2019

Disetujui: 24-03-2020

Diterbitkan: 01-04-2020
Kata kunci: Relaksasi Autogenik, ODHA, Gastritis, Gejala, Rumah Sakit Wangaya.

Cite Pasal Ini: Surasta, I.W., Suardana, I.K., Labir, I.K. 2020. Relaksasi autogenik menurunkan keluhan gastritis pada orang dengan infeksi HIVAIDS (ODHA) di RSUD Wangaya, Bali, Indonesia. Intisari Sains Medis 11(1): 301-305. D0I: 10.15562/ism.v11i1.564

\section{PENDAHULUAN}

Masyarakat terkini dituntut banyak kewajiban dan tanggung jawab dalam kehidupan seharihari, tekanan mental yang mengakibatkan stress dalam menghadapi banyak persoalan hidup yang tersupresi kedalam diri. ${ }^{1} \mathrm{Hal}$ ini berdampak pada gangguan sistem dalam tubuh yang terjadi juga pada organ percernaan yaitu gastritis. ${ }^{2}$ Gastritis terdiri dari dua tipe yaitu gastritis akut dan gastritis kronis. Faktor penyebab gastritis akut dan gastritis kronis adalah pola makan yang tidak teratur, konsumsi obat penghilang nyeri jangka panjang, konsumsi kopi, alkohol, merokok, stres fisik, stres 
psikologis, kelainan autoimun, chrone disease, penyakit bile reflux, infeksi bakteri, dan penyakit lain seperti virus, infeksi parasit dan gagal hati atau ginjal. $^{3}$

Hasil penelitian dan pengamatan yang dilakukan oleh Departemen Kesehatan RI angka kejadian gastritis di beberapa kota di Indonesia ada yang tinggi mencapai 91,6\% yaitu 2 di kota Medan, lalu di beberapa kota lainnya seperti Surabaya $31,2 \%$, Denpasar 46\%, Jakarta 50\%, Bandung 32,5\%, Palembang 35,35, Aceh 31,7\%, dan Pontianak $31,2 \% .{ }^{4}$ Hal tersebut disebabkan oleh pola makan yang kurang sehat, tekanan psikologis dalam kehidupan/stres. Tahun 2009 penyakit gastritis merupakan salah satu penyakit didalam sepuluh penyakit terbanyak pada pasien rawat inap di rumah sakit seluruh Indonesia dan menyerang lebih banyak perempuan dari pada laki-laki dengan jumlah kasus 30.154 orang. ${ }^{4}$ Berdasarkan studi dokumentasi kasus yang ditangani di RSUD Wangaya diperoleh bahwa kasus gastritis menduduki urutan keempat setelah ISPA, jantung, hipertensi, dan dibetes mellitus dilihat dari angka kunjungan pada tahun 2014 sebanyak 320 dan pada tahun 2015 meningkat menjadi $482 .{ }^{5}$

Relaksasi merupakan suatu keadaan dimana seseorang merasakan bebas mental dan fisik dari ketegangan dan stres. ${ }^{6}$ Teknik relaksasi bertujuan agar individu dapat mengontrol diri ketika terjadi rasa ketegangan dan stres yang membuat individu merasa dalam kondisi yang tidak nyaman. ${ }^{7}$ Autogenik memiliki makna pengaturan sendiri aktifitas system saraf otonom yang mengendalikan system tubuh. Autogenik merupakan salah satu contoh dari teknik relaksasi yang berdasarkan konsentrasi pasif dengan menggunakan persepsi tubuh (misalnya, tangan merasa hangat dan berat) yang difasilitasi oleh sugesti diri sendiri. ${ }^{8}$ Menurut Goldbeck L dan Schmid K, relaksasi autogenik merupakan relaksasi yang bersumber dari diri sendiri dengan menggunakan kata-kata atau kalimat pendek yang bisa membuat pikiran menjadi tenang. ${ }^{8}$

ODHA kerap mendapat stigma (cap negatif) dan diskriminasi dari masyarakat di sekitarnya. ${ }^{9}$ Hal ini tampak dari begitu banyak penderita menerima perlakuan yang berbanding terbalik sebelum terdiagnosa HIV. Berkaitan dengan tersebut maka pasien ODHA kerap menghadapi stigma dan diskriminasi pada dalam rentang waktu Panjang selama bertahun-tahun. ${ }^{9}$ Hal ini muncul karena terdapat kesalahan persepsi atas HIV dan AIDS terutama media penularan serta pandangan mengenai masalah kesehatan ini di nasyarakat.

Keluhan fisik yang sering disampaikan pada orang dengan HIV-AIDS adalah menurunnya nafsu makan, nyeri lambung akibat pemberian obat yang cukup lama dan stress yang berkepanjangan akibat beban psikologis. ${ }^{9}$ Berkaitan dengan tersebut maka memungkinkan diberikan terapi psikologis untuk mengurangi beban mentalnya. Berdasarkan pemaparan di atas, penelitian ini bertujuan untuk mengetahui apakah relaksasi autogenik dapat menurunkan keluhan gastritis pada orang dengan HIV-AIDS (ODHA) di RSUD Wangaya, Bali, Indonesia.

\section{METODE}

Penelitian ini merupakan penelitian quasi-eksperimen dengan menggunakan rancangan pre and post test design without control group. Penelitian dilaksanakan di KPAD Badung, KDS Setia Kawan Badung, dan RSUD Wangaya menggunakan teknik purposive sampling terhadap 21 responden penelitian yang telah memenuhi kriteria inklusi dan eksklusi.

Penelitian ini akan dilakukan pada pasien ODHA yang mengeluh gejala gastritis seperti Rasa mual, nyeri ulu hati, muntah, perut kembung, maupun kehilangan selera makan dalam rentangan waktu selama 1 bulan. Responden penelitian kemudian melakukan latihan relaksasi autogenik 3 kali dan selanjutnya melakukan di rumah selama 4 minggu dibawah pengawasan enumerator/fasilitator, setelah itu evaluasi gejala/keluhan gastritis. Teknik relaksasi autogenik yang dilakukan pada penelitian dimulai dengan pengaturan posisi tubuh, posisi berbaring, maupun bersandar ditempat duduk. Sebaiknya individu berbaring di karpet atau di tempat tidur, kedua tangan di samping tubuh, telapak tangan menghadap ke atas, tungkai lurus sehingga tumit dapat menapak di permukaan lantai. Bantal yang tipis dapat diletakkan di bawah kepala atau lutut untuk menyangga, asalkan tubuh tetap nyaman dan posisi tubuh tetap lurus. Responden penelitian harus melepaskan jam tangan, cincin, kalung dan perhiasan yang mengikat lainnya serta longgarkan pakaian yang ketat.

Ada enam langkah dalam relaksasi autogenik yaitu perasaan berat, perasaan hangat, ketenangan dan kehangatan pada jantung, perasaan dingin di dahi, dan ketenangan pernafasan. Langkah relaksasi dengan menggunakan basic six dan fokus pada pernapasan dilakukan selama kurang lebih 10 menit. Kemudian setelah latihan nafas dilanjutkan dengan pengalihan kepada kalimat "saya merasa tenang dan nyaman berada di sini" sebagai sugesti. Responden disugestikan untuk memasukan kalimat tersebut ke dalam pikirannya dan diintruksikan supaya tenggelam dalam ketenangan ketika mendengar kalimat tersebut. Akhir dari relaksasi autogenik responden merasakan hangat, berat, dingin dan tenang. Tahap akhir dari relaksasi 
ini responden diharapkan mempertahankan posisi dan mencoba menempatkan perasaan rileks ini ke dalam memori sehingga relaksasi autogenik dapat diingat saat merasa nyeri.

Dalam melakukan pengamatan peneliti menggunakan instrument penelitian yang telah teruji validitas dan reliabelitasnya. Pedoman observasi yang digunakan untuk menilai tingkat kesembuhan responden gastritis kronis adalah lembar observasi dengan 4 kriteria penilaian yang terdiri dari empat skala likert yaitu: masih ada 5 gejala gastritis (1), 3 gejala gastritis (2), 1 gejala gastritis (3), sembuh tidak ada gejala (4). Adapun seluruh data yang diperoleh pada penelitian ini kemudian dianalisis menggunakan piranti lunak SPSS versi 17 untuk Windows.

\section{HASIL PENELITIAN}

Karakteristik responden penelitian dapat dilihat pada Tabel 1 dimana sebagian besar berjenis kelamin laki-laki $(61,9 \%)$ dan bekerja sebagai ibu rumah tangga $(28,6 \%)$. Berdasarkan status perkawinan, sebagian besar responden telah menikah

\section{Tabel 1 Karakteristik dasar responden berdasarkan data} demografis

\begin{tabular}{lcc}
\hline Variabel & Jumlah (N=21) & Persentase (\%) \\
\hline Jenis Kelamin & & \\
$\quad$ Laki-laki & 13 & 61,9 \\
$\quad$ Perempuan & 8 & 36,1 \\
Pekerjaan & & \\
$\quad$ Ibu rumah tangga & 6 & 28,6 \\
Pedagang & 5 & 23,8 \\
Petani & 3 & 14,3 \\
Supir & 4 & 19,0 \\
Buruh & 3 & 14,3 \\
Status perkawinan & & \\
Kawin & 17 & 81,0 \\
Tidak kawin & 1 & 4,8 \\
Janda & 1 & 4,8 \\
Duda & 2 & 9,4 \\
Tempat asal & & \\
Kuta Selatan & 1 & 4,8 \\
Kuta & 3 & 14,3 \\
Kuta Utara & 3 & 14,3 \\
Mengwi & 6 & 28,6 \\
Abiansemal & 4 & 19,0 \\
Petang & 3 & 14,3 \\
Tabanan & 1 & 4,8 \\
\hline & &
\end{tabular}

$(81,0 \%)$. Para responden penelitian sebagian besar berasal dari kecamatan Mengwi yakni sebanyak 28,6\%, diikuti dengan Abiansemal sebanyak 19,0\%, dan masing-masing dari Kuta, Kuta Utara, dan Petang berjumlah 14,3\% (Tabel 1).

Pengukuran intensitas keluhan yang dirasakan responden yang berkaitan dengan gejala gastristis dilihat dari aspek: keluhan mual, nyeri hulu hati, muntah, perut kembung/begah, dan selera makan dapat dilihat pada Tabel 2 dimana pengukuran dilakukan sebanyak 2 kali. Hasil penelitian menunjukkan bahwa sebagian besar keluhan mual yang dirasakan responden sebelum perlakuan bersifat kadang-kadang $(71,4 \%)$ dan setelah relaksasi autogenik persentasenya berkurang menjadi $52,4 \%$. Tabel 2 juga menunjukkan bahwa keluhan nyeri ulu hati yang dirasakan responden sebelum perlakuan relaksasi autogenik sebagian besar bersifat kadang-kadang $(52,4 \%)$ dan setelah relaksasi autogenik sebagian besar bersifat jarang $(52,4 \%)$. Keluhan muntah yang dialami responden sebelum perlakuan relaksasi autogenik sebagian besar bersifat kadang-kadang $(52,4 \%)$ dan setelah relaksasi autogenik sebagian besar bersifat jarang (66,7\%). Kejadian perut Kembung/begah yang dialami responden sebelum perlakuan bersifat kadangkadang $(52,4 \%)$ dan setelah relaksasi autogenik sebagian besar bersifat jarang $(57,1 \%)$. Kemudian keluhan kehilangan selera makan yang dirasakan responden sebelum perlakuan bersifat kadangkadang $(61,9 \%)$ dan setelah relaksasi autogenik sebagian besar bersifat jarang (42,9\%) (Tabel 2).

Berdasarkan Tabel 3 terlihat bahwa dari 21 responden rata-rata nilai keluhan gastritis sebelum perlakuan adalah 1,77 sedangkan rata-rata nilai keluhan gastritis responden setelah perlakuan adalah 1,53. Uji beda berpasangan (Paired T-test) menunjukkan nilai sebesar $0,002(\mathrm{p}>0,05)$ dimana dapat dikatan terdapat perbedaan yang bermakna keluhan gatristis sebelum dan setelah diberikan relaksasi autogenik pada ODHA (Tabel 3).

\section{PEMBAHASAN}

Keberadaan kelompok KDS Setia Kawan Badung dalam melakukan perekrutan dan pembinaan pada klien HIV-AIDS (ODHA) sangat dibutuhkan dan sangat berperan dalam memberikan semangat untuk berusaha menangani anggota kelompoknya yang menderita dan ikut merasakan kesulitan yang dialami para klien yang mengalami masalah HIV-AIDS (ODHA). Hal ini senada dengan Yayasan Spiritia yang menggagas terbentuknya kelompok peduli HIV-AIDS (ODHA) sebagai organisasi sosial meringankan masalah yang dialami pasien HIV-AIDS (ODHA) seperti yang terjadi di RSUD 
Tabel 2 Keluhan gastritis yang dialami oleh responden penelitian sebelum dan setelah pemberian intervensi relaksasi autogenik

\begin{tabular}{lcccc}
\hline & \multicolumn{3}{c}{ Pre-test } & \multicolumn{3}{c}{ Post-test } \\
\cline { 2 - 5 } Keluhan & Jumlah (N=21) & \% & Jumlah (N=21) & $\%$ \\
\hline Rasa Mual & & & & \\
$\quad$ Jarang & 4 & 19,0 & 10 & 47,6 \\
$\quad$ Kadang-kadang & 15 & 71,4 & 11 & 52,4 \\
$\quad$ Sering & 2 & 9,5 & 0 & 0 \\
Nyeri ulu hati & & & & \\
$\quad$ Jarang & 9 & 42,9 & 11 & 52,4 \\
$\quad$ Kadang-kadang & 11 & 52,4 & 9 & 42,9 \\
$\quad$ Sering & 1 & 4,8 & 1 & 4,8 \\
Muntah & & & & \\
$\quad$ Jarang & 8 & 38,1 & 14 & 66,7 \\
$\quad$ Kadang-kadang & 11 & 52,4 & 6 & 28,6 \\
$\quad$ Sering & 2 & 9,5 & 1 & 4,8 \\
Perut kembung & & & & \\
$\quad$ Jarang & 8 & 38,1 & 12 & 57,1 \\
$\quad$ Kadang-kadang & 11 & 52,4 & 8 & 38,1 \\
$\quad$ Sering & 2 & 9,5 & 1 & 4,8 \\
Hilang selera makan & & & & \\
$\quad$ Jarang & 5 & 23,8 & 9 & 42,9 \\
$\quad$ Kadang-kadang & 13 & 61,9 & 8 & 38,1 \\
$\quad$ Sering & 3 & 14,3 & 4 & 19,0 \\
\hline
\end{tabular}

Tabel 3 Perbedaan nilai keluhan gastritis responden sebelum dan setelah perlakuan

\begin{tabular}{lccccc}
\hline Variabel & $\mathbf{n}$ & Rerata & Simpang baku & Selisih rerata & $\mathbf{p}$ \\
\hline Relaksasi autogenik & & & & & \\
Sebelum perlakuan & 21 & 1,77 & 0,478 & 0,24 & 0,002 \\
Setelah perlakuan & 21 & 1,53 & 0,375 & & \\
\hline
\end{tabular}

Wangaya, Denpasar. Keberadaan pasien HIV-AIDS (ODHA) dalam kelompok KDS Setia Kawan Badung sesuai karakteristiknya secara umum kelopok umur dalam kondisi masih produktif, kebanyakan laki-laki $61,9 \%$, perkerjaan pedagang dan ibu rumah tangga yang mendominasi $62,4 \%$, dari tempat domisili pasien yang terbanyak ada di Mengwi hal ini dikarenakan KPAD Badung KDS Setia Kawan berada di wilayah Mengwi sehingga klien banyak berasal dari wilayah ini tidak menutup kemungkinan banyak dari tempat lain karena informasi, kesadaran untuk ikut bergabung dalam kelompok masih rendah, sehingga masih perlu diinformasikan ke masyarakat akan kepedulian terhadap masalah HIV-AIDS (ODHA).
Kegiatan relaksasi autogenik adalah relaksasi merupakan suatu keadaan dimana seseorang merasakan bebas mental dan fisik dari ketegangan dan stres. ${ }^{10}$ Teknik relaksasi bertujuan agar individu dapat mengontrol diri ketika terjadi rasa ketegangan dan stres yang membuat individu merasa dalam kondisi yang tidak nyaman. ${ }^{11}$ Hal inilah yang dibutuhkan oleh pasien HIV-AIDS (ODHA) yakni keadaan yang nyaman bebas dari tekanan mental untuk meningkatkan sistem imun dirinya sendiri. ${ }^{12}$ Rasa tertekan karena stigma masyarakat pada pasien ODHA akan menyebabkan mereka rentan terhadap stress sehingga efek samping obat dalam jangka watu panjang akan berpengaruh pada sistem pencernaannya dan menurunkan sistem imun tubuh..$^{13,14}$

Sesuai dengan tujuan umum penelitian ini, maka setelah dilakukan analisis bivariat untuk menguji kemaknaan perbedaan intervensi sebelum relaksasi autogenik dan sesudah relaksasi autogenik terhadap keluhan gastritis pada pasien ODHA, didapatkab perbedaan bermakna keluhan gastritis sebelum dan setelah diberikan relaksasi autogenic pada ODHA. Hal ini sesuai dengan teori relaksasi psikologis yang mendalam memiliki manfaat bagi kesehatan yang memungkinkan tubuh menyalurkan energi untuk perbaikan dan pemulihan, serta memberikan kelonggaran bagi ketegangan akibat pola-pola kebiasaan. ${ }^{15}$ Teknik relaksasi autogenik mengacu pada konsep baru. Selama ini, fungsi-fungsi tubuh yang spesifik dianggap berjalan secara terpisah dari pikiran yang tertuju pada diri sendiri. Teknik relaksasi ini membantu individu dalam mengalihkan secara sadar perintah dari diri individu tersebut. Hal ini dapat membantu melawan efek akibat stres yang berbahaya bagi tubuh. Teknik relaksasi autogenik memiliki ide dasar yakni untuk mempelajari cara mengalihkan pikiran berdasarkan anjuran sehingga individu dapat menyingkirkan respon stres yang mengganggu pikiran. ${ }^{16}$

Relaksasi autogenik akan membantu tubuh untuk membawa perintah melalui autosugesti untuk rileks sehingga dapat mengendalikan pernafasan, tekanan darah, denyut jantung serta suhu tubuh. ${ }^{16}$ Imajinasi visual dan mantra-mantra verbal yang membuat tubuh merasa hangat, berat dan santai merupakan standar latihan relaksasi autogenik. ${ }^{17}$ Sensasi tenang, ringan dan hangat yang menyebar ke seluruh tubuh merupakan efek yang bisa dirasakan dari relaksasi autogenik. ${ }^{16,17}$ Tubuh merasakan kehangatan, merupakan akibat dari arteri perifer yang mengalami vasodilatasi, sedangkan ketegangan otot tubuh yang menurun mengakibatkan munculnya sensasi ringan. Perubahan yang terjadi selama maupun setelah relaksasi 
mempengaruhi kerja saraf otonom. Respon emosi dan efek menenangkan yang ditimbulkan oleh relaksasi ini mengubah fisiologi dominan simpatis menjadi dominan sistem parasimpatis. ${ }^{16,17}$

Menurut penelitian Stetter F pada tahun 2002 dimana dari 60 pelajar dari 35 negara, ditemukan efek besar pada perbandingan untuk pre dan post intervensi teknik relaksasi autogenik, efek menengah terhadap kelompok kontrol, dan tidak ada efek bila dibandingkan dengan terapi psikologis yang lain. ${ }^{18}$ Relaksasi autogenik efektif dilakukan selama 20 menit dan relaksasi autogenik dapat dijadikan sebagai sumber ketenangan selama sehari. ${ }^{16}$ Berdasarkan penelitian yang dilakukan oleh Setyawati A relaksasi autogenik yang dilakukan sebanyak 3 kali juga memiliki pengaruh yang signifikan terhadap penurunan tekanan darah dan kadar gula darah pada klien diabetes melitus tipe 2 dengan hipertensi. ${ }^{19}$ Berkaitan dengan hal tersebut maka relaksasi autogenik efektif dalam menurunkan kejadian gastritis yang diinduksi oleh stress pada pasien ODHA.

\section{SIMPULAN}

Hasil penelitian ini menunjukkan bahwa pemberian intervensi terapi relaksasi autogenik pada ODHA yang memiliki keluhan gastritis menunjukkan terdapat perbaikan yang bermakna terhadap nilai keluhan yang dirasakan dibandingkan sebelum pemberian terapi relaksasi autogenik

\section{KONFLIK KEPENTINGAN}

Tidak ada.

\section{ETIKA PENELITIAN}

Penelitian ini telah mendapat persetujuan etik oleh Komisi Etik, Poltekkes Denpasar, Bali, Indonesia sebelum penelitian berjalan.

\section{PENDANAAN}

Penulis bertanggung jawab terhadap pendanaan penelitian ini tanpa melibatkan pihak sponsor, beasiswa, ataupun sumber pendanaan lainnya.

\section{KONTRIBUSI PENULIS}

Seluruh penulis berkontribusi terhadap penelitian ini baik dari perencaan proposal penelitian, pencarian data, analisis data penelitian, hingga interpretasi dan penyusunan naskah publikasi.

\section{DAFTAR PUSTAKA}

1. Yaribeygi H, Panahi Y, Sahraei H, Johnston TP, Sahebkar A. The impact of stress on body function: A review. EXCLI J. 2017;16:1057-1072.

2. Goodwin RD, Cowles RA, Galea S, Jacobi F. Gastritis and mental disorders. J Psychiatr Res. 2013;47(1):128-132.

3. Glickman JN, Antonioli DA. Gastritis. Gastrointest Endosc Clin N Am. 2001;11(4):717-vii.

4. Departemen Kesehatan Republik Indonesia. Angka Kejadian Gastritis di Indonesia: Profil Kesehatan Indonesia. Kementerian Kesehatan: Jakarta. 2010.

5. Rumah Sakit Umum Daerah Wangaya. 10 Besar Penyakit di RSUD Wangaya. Pemerintah Kota Denpasar:Bali. 2015.

6. Manzoni GM, Pagnini F, Castelnuovo G, Molinari E. Relaxation training for anxiety: a ten-years systematic review with meta-analysis. BMC Psychiatry. 2008;8:41.

7. Richter JM, Sloan R. Stress: a relaxation technique. Am J Nurs. 1979;79(11):1960-1963.

8. Goldbeck L, Schmid K. Effectiveness of autogenic relaxation training on children and adolescents with behavioral and emotional problems. J Am Acad Child Adolesc Psychiatry. 2003;42(9):1046-1054.

9. Mahajan AP, Sayles JN, Patel VA, et al. Stigma in the HIV/ AIDS epidemic: a review of the literature and recommendations for the way forward. AIDS. 2008;22 Suppl 2(Suppl 2): S67-S79.

10. Shapiro S, Lehrer PM. Psychophysiological effects of autogenic training and progressive relaxation. Biofeedback Self Regul. 1980;5(2):249-255.

11. Biondi M, Valentini M. Relaxation treatments and biofeedback for anxiety and somatic stress-related disorders. Riv Psichiatr. 2014;49(5):217-226.

12. Wahbeh H, Haywood A, Kaufman K, Zwickey H. Mind-Body Medicine and Immune System Outcomes: A Systematic Review. Open Complement Med J. 2009;1:25-34.

13. Kotler DP. HIV infection and the gastrointestinal tract. AIDS. 2005;19(2):107-117.

14. Brenchley JM, Douek DC. HIV infection and the gastrointestinal immune system. Mucosal Immunol. 2008;1(1):23-30.

15. Ikei H, Komatsu M, Song C, Himoro E, Miyazaki Y. The physiological and psychological relaxing effects of viewing rose flowers in office workers. J Physiol Anthropol. 2014;33(1):6

16. Kanji N, White A, Ernst E. Autogenic training to reduce anxiety in nursing students: randomized controlled trial. J Adv Nurs. 2006;53(6):729-735.

17. Varvogli L, Darviri C. Stress Management Techniques: evidence-based procedures that reduce stress and promote health. Health Science Journal. 2011;5(2):74-89.

18. Stetter F, Kupper S. Autogenic training: a meta-analysis of clinical outcome studies. Appl Psychophysiol Biofeedback. 2002;27(1):45-98.

19. Setyawati A. Pengaruh Relaksasi Otogenik terhadap Penurunan Tekanan Darah dan Gula Darah pada Klien Diabetes Miletus Tipe 2 di Instalasi Rawat Inap Rumah Sakit di D.I.Y dan Jawa Tengah. [Thesis]. Fakultas Ilmu Keperawatan Program Studi Pasca Sarjana Ilmu Keperawatan Kekhususan Keperawatan Medikal Bedah; Jakarta. 2010.

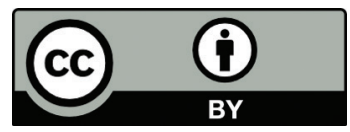

This work is licensed under a Creative Commons Attribution 